\title{
PERSPEKTÍVY ROZVOJA VIDIECKYCH SÍDIEL V OKRESE TRNAVA Z POHLADU RÍMSKOKATOLÍCKYCH KŇAZOV (VÝSLEDKY SOCIOLOGICKÉHO PRIESKUMU)
}

\author{
Milena Moyzeová, Zita Izakovičová
}

\begin{abstract}
Priests in rural settlements represent a communication base and their main mission is to care for the spiritual life of parishioners and to cooperate in education and upbringing of the youth through religious studies at the local elemental schools. It is therefore necessary to assess the attitude and participation of the Church in questions concerning the communal life and its possible perspectives. Participation of the Roman Catholic Church in the development and management of communes in the district of Trnava has been assessed by means of sociological research. The aim of the paper is to present opinion and attitude of the Roman Catholic priests active in 23 parishes to the questions concerning the environmental quality, specification of environmental, economic, and social problems, as well as evaluation of human potential.
\end{abstract}

Keywords: rural settlements, environmental quality, rural development, interview, Roman Catholic priests

\section{Úvod}

Od ukončenia protireformačných a rekatolizačných tendencií je v slovenskej spoločnosti výrazne dominantnou rímskokatolícka cirkev (Majo, 2017). Podl'a Štatistickej ročenky SR (2017) z hl'adiska náboženskej štruktúry je na Slovensku 68,9 \% obyvatel'ov a v okrese Trnava 93,39 \% obyvatel'ov rímskokatolícke vierovyznania. Okres Trnava zahŕňa farnosti a filiálky trnavského dekanátu, smolenického a hlohoveckého dekanátu. Farnosti a filiálky trnavského dekanátu - Bohdanovce nad Trnavou/Šelpice, Brestovany/Horné Lovčice, Cífer/Pác, Hrnčiarovce nad Parnou, Križovany nad Dudváhom/Vlčkovce, Majcichov, Opoj, Ružindol/ Biely Kostol, Suchá nad Parnou/Košolná, Zvončín, Špačince, Trnava - Kopánka, Trnava - Prednádražie, Trnava - Modranka, Trnava Tulipán, Trnava - sv. Mikuláša, Voderady/ Pavlice, Slovenská Nová Ves, Zavar/Dolné Lovčice, Zeleneč. Farnosti a filiálky smolenického dekanátu Boleráz/Klčovany, Buková, Dechtice, Dlhá/Borová, Dobrá Voda, Dolná Krupá/Horná Krupá, Dolné Dubové/Radošovce, Dolné Orešany, Horné Orešany/Lošonec, Jaslovské Bohunice/Paderovce, Kátlovce, Naháč/Horné Dubové, Smolenice/Smolenická Nová Ves, Trstín/Bíňovce a farnosti hlohoveckého dekanátu - Bučany a Malženice. 
Ciel’om predkladaného príspevku je v nadväznosti na získané výsledky z krajinnoekologického a sociologického prieskumu realizovaného vo vidieckych sídlach okresu Trnava:

- pokračovat' v hodnotení rozvojových podmienok vybraných vidieckych sídiel a rozšírit' doterajšie spektrum oslovených respondentov (starostovia vidieckych sídiel, obyvatelia, farmári a pod.) o predstavitel'ov rímskokatolíckej cirkvi,

- formou riadených rozhovorov analyzovat' názory rímskokatolíckych kňazov na život v obciach a možnosti d’alšieho rozvoja sídiel v kontexte s trvalo udržatel'ným rozvojom.

\section{Teoreticko-metodické východiská}

Sociologický prieskum sme realizovali s 23 rímskokatolíckymi (RK) kňazmi v sídlach Trnava - Modranka, Zeleneč, Boleráz, Jaslovské Bohunice, Dechtice, Suchá nad Parnou, Naháč, Trstín, Buková, Smolenice, Horné Orešany, Bohdanovce nad Trnavou, Dlhá, Ružindol, Pavlice, Majcichov, Cífer, Dolná Krupá, Dolné Dubové, Dobrá Voda, Kátlovce, Križovany nad Dudváhom a Voderady.

Pomocou otázok kladených v rámci rozhovoru „face to face“ sme sa snažili získat' obraz o priamej participácii RK kňazov na živote v obci, na aktivitách, ktoré sa vobci realizujú a ktoré prispievajú k zvyšovaniu kvality životného prostredia, kvality života a zvyšovaniu environmentálneho povedomia obyvatel'ov. pre prieskum sme si stanovili 2 hypotézy.

Hypotéza 1: Predpokladáme, že rímskokatolícki kňazi vo vidieckych sídlach okresu Trnava zastávajú významné miesto v spoločenskom živote.

Hypotéza 2: Predpokladáme, že rímskokatolícki kňazi sa aktívne zapájajú do environmentálnych aktivít, ktoré prispievajú k zvyšovaniu kvality životného prostredia, ovplyvňujú hodnotovú orientáciu a ekologické povedomia obyvatel'ov a tým ich postoje $\mathrm{k}$ životnému prostrediu, k prírodným zdrojom a kultúrnym hodnotám a trvalo udržatel'nému rozvoju obce.

Názory získané $\mathrm{z}$ riadených rozhovorov nám doplnili informácie publikované v prácach Izakovičová a kol. (2006), Izakovičová a kol. (2008), Moyzeová (2014), Moyzeová a kol. (2015), Moyzeová, Izakovičová (2016) a pod.

Interview patrí medzi oblúbené, najvýhodnejšie, ale súčasne najnáročnejšie nástroje kvalitatívneho výskumu (Denzin, Lincoln, 1994). Ako jeden zo spôsobov ako získat' sociálno-psychologické informácie (Maříková a kol., 1996) sme si ho vybrali ako vhodný nástroj na vyjadrenie pocitov a názorov účastníkov rozhovoru cez ich odpovede na 8 okruhov otázok:

1. Ako by ste zhodnotili spoločenské dianie vo vašej obci? Aké akcie (spoločenské, kultúrne a pod.) organizujete? Kto je ich hlavným iniciátorom /organizátorom? 
2. Zapájate sa do spoločenského diania $\mathrm{v}$ obci? Ak áno, akou formou?

3. Ako by ste zhodnotili aktivitu miestnych l'udí?

4. Aké problémy máte $\mathrm{v}$ obci? Vymenujte ich prosím. Ako tieto problémy vnímate $\mathrm{z}$ vášho pohl'adu? Sú to problémy, ktoré sú závažné a prispievate $\mathrm{k}$ ich riešeniu, alebo naopak, nie je potrebné vzhl'adom $\mathrm{k}$ vašej profesii sa $\mathrm{k}$ nim vyjadrovat'?

5. Ktoré problémy by ste definovali ako najzávažnejšie, potrebné prioritne riešit?

6. V čom vidíte hlavné bariéry rozvoja vašej obce?

7. Ako sa RK kňazi zapájajú do manažmentu obce? Čo si myslíte, v akej konkrétnej oblasti (v rámci manažmentu a rozvoja obce) by mali RK kňazi pôsobit?

8. Ako sa Vy konkrétne zapájate do environmentálnych aktivít? Vymenujte tie aktivity, ktoré realizujete a s kým.

Z hl'adiska vekovej štruktúry sa prieskumu zúčastnilo 6 farárov vo vekovej kategórii 18 - 39 rokov, 9 farárov vo vekovej kategórii od $40-59$ rokov a 8 farárov vo vekovej kategórii nad 60 rokov. 15 farárov pôsobí vo farnosti viac ako 5 rokov a 8 farárov pôsobí vo farnosti menej ako 5 rokov.

Výsledky prieskumu uvádzame konceptuálnou analýzou (Chrenščová, 2011), ako sumarizáciu, kategorizáciu a interpretáciu názorov 23 RK kňazov. Pre zachovanie ich anonymity sme odpovede označili číslami v zátvorke, ktoré môžu mat' vyššie hodnoty ako 23 , nakol'ko sme číslami označili všetky sídla v okrese Trnava a tých je 45 .

\section{Výsledky analýzy}

\section{Ako by ste zhodnotili spoločenské dianie vo vašej obci? Aké akcie (spoločenské, kultúrne a pod.) organizujete? Kto je ich hlavným iniciátorom /organizátorom?}

Spoločenské dianie vo vybraných obciach okresu Trnava z pohl'adu RK kňazov bolo hodnotené značne diferencovane. V odpovediach síce prevažovalo pozitívne hodnotenie, ale našli sa aj kritickejšie názory. Spoločenské dianie je slabé s určitými rezervami, ale s optimistickou prognózou $(12,41,31)$. Spoločenské dianie v obci je koncentrované do zábavy a futbalu a je často spojené s devastáciou životného prostredia. Je tu menšia pasivita l'udí pre verejný záujem (1). Spoločenské dianie v obci existuje (6). Aj v d’alších obciach bolo hodnotené pozitívne ako dobré $(2,31,14,38,22)$...sme tu ako jedna rodina (4). Vobci je vel'a spolkov, máme vel'a aktivit a l'udia sa akcií zúčastňujú. Aj kultúrne akcie spájame so svätou omšou. V obci je spolupráca medzi farským úradom a obecným úradom. Spolu sa podporujú aj s miestnou školou (38) ...celá obec sa za posledné 
roky skultúrnila. Urobila sa plynofikácia, kanalizácia a ja ich pri týchto aktivitách povzbudzujem... Spoločenské dianie v obci hodnotím pozitívne (37). Našu obec hodnotím ako vel'mi aktívnu (18). Kultúrna činnost' je dobrá. Máme akcie hudobné, vobci je spevokol, aktívni sú požiarnici aj dôchodcovia (38) ...hodnotit' spoločenské dianie v obci je otázkou hodnotenia celej spoločnosti, nielen l'udí v obci (20) ... V spoločnosti prevláda silný individualizmus. Ludia sedia doma pri televízii a mládež za počítačmi...Spoločenské dianie vobci je sústredené na futbalové aktivity (11). Vnašej obci je spoločenské dianie priemerné (3). Spoločenské dianie v obci je t'ažké hodnotit' dvoma vetami. Som verejný činitel' a všetci sú ovplyvňovaní šenkom a politikou. Kedysi sa žilo z tradicií, sviatky bez divadla neexistovali, perie sa páralo, l’udia si spievali. Zmeny v spoločenskom diani sa odzrkadlili aj na živote v obci. Spoločenské dianie je sústredené na ples, na diskotéky a oslavy životných jubileí. Aj farské úrady majú svoje mínusy, ale tie sú postavené na financiách. Mali by existovat' farské centrá, ktoré by plnili charitatívnu úlohu. OÚ podporuje radšej futbal ako kostol. Nejde iba o l'udí veriacich, ale treba robit' akcie pre všetkých l'udi spolu.

\section{Zapájate sa do spoločenského diania v obci? Ak áno, akou formou?}

Väčšina oslovených RK kňazov sa akcií organizovaných starostom a miestnym zastupitel'stvom nezúčastňuje, nakol'ko cirkev má vlastné akcie napríklad púte, ktoré si organizuje sama. Napriek tomu, spolupráca medzi obecným úradom a farským úradom bola hodnotená pozitívne $(37,4)$. Podl'a názoru opýtaných, aktivita stúpa najmä pred vol'bami, kedy je viac akcií (12)...Zúčastñujeme sa na kultúrnych akciách napriklad na oslavách požiarnikov, ale nie sú to systematické veci, skôr príležitostné $(20,3,31,38)$. V niektorých obciach sa akcií zúčastňuje pán farár vždy, ked' ho zavolajú $(41,15)$. Ide predovšetkým o akcie ako sú stretnutie s dôchodcami alebo tradičný Mikuláš. Pán farár sa zúčastňuje na rôznych stretnutiach najmä s det’mi a dôchodcami (11). ...V našej obci je takouto spoločenskou akciou Pochovávanie basy (38). V obci je kňaz členom rady školy a preto o akciách v obci je informovaný a často sa ich aj zúčastňuje (31). Ide predovšetkým o kultúrno-spoločenské podujatia ako Cíferská hudobná jar a Cíferská hudobná jeseň. V obci sa organizujú Dni dôchodcov, Deň matiek, Vianoce a mnoho d'alších akcií (1). Rozvíja sa futbal žiakov a dorastencov. Funguje šachový krúžok a miestny kňaz učí deti aj rodičov anglický jazyk a hru na organe. Spolupráca farského úradu a obecného úradu funguje, ale akcie si robí každý sám (6) ...Spoločné akcie nemáme. Spoločenské akcie si spoločne organizujú farský aj obecný úrad (14) ...Kultúrnych akcií sa pravidelne zúčastňujeme... (44, 2). Ja sa iba občas zúčastňujem na spoločenskom dianí v obci (22). Snažím sa zúčastňovat' od spoločenských akcii cez pracovné (18). Vnašej obci je hlavným kultúrnym dianím diskotéka (10). V niektorých obciach sa podla slov oslovených respondentov spoločenské dianie spája s nekultúrnost'ou obyvatel'ov 
a vulgárnost’ami a preto sa takýchto akcií RK kňazi ani zúčastňovat’ nechcú. ...Nie je náplňou farára aby sa angažoval v otázkach rozvoja obce (12) ...Tých akcii je tak málo, že ani nie je sa do čoho zapájat’... Farár nechodi na obecné schôdze, nezaujíma ho to a ani nechce kritizovat'...

\section{Ako by ste zhodnotili aktivitu miestnych l'udí?}

Hodnotit' aktivity miestnych l'udí, či sú aktívni a zapájajú sa do diania v obci, alebo nie sú aktívni, bolo z pohl'adu RK kňazov dost' náročné, nakol'ko sa nedá hodnotit' všetkých obyvatel'ov v sumáre...Hodnotit' l'udi je ako hodnotit' miešaný tovar. Sú tu l'udia aj obetavi aj taki ktorým narástli obe ruky naopak (37) ...Nájdu sa aj aktívni a sú aj pasívni...Povedat' o všetkých že sú neaktívny nemôžem...Zopár aktívnych a väčšina zatial' pasivnych, je jeden $\mathrm{z}$ názorov na aktivitu miestnych l'udí (31). Sú aj menej aktívni, ktorí sa spoliehajú na druhých (12). Aj ked' sú menej aktívni, sú aj výnimky. Možno v porovnaní s inými obcami sú l'udia dost' l'ahostajni a vel'a kritizujú a málo sa pričiňujú. Aj veriaci sú dost' l'ahostajni (12)...Pre dobro rodiny, stráca zmysel pre dianie v obci (44)...Ide to stále $k$ horšiemu. Ludia robia dlho a nie je čas na spoločné akcie a ani záujem... Hodnotit' l'udí je všeobecný problém (20). Veci sa dajú presadit' iba cez politické strany. Ludia sa vedia angažovat' a zapájat', ale nájdu sa aj pasívni a kritickí obyvatelia (11). Pozitívnym príkladom ochoty zapájat' sa do aktivít v obci je aj vybudovanie fary na ktorej obyvatelia zadarmo odpracovali desiatky hodín... Aktívni sú skôr dôchodcovia, respektive starši l'udia (6)...Sú aktívni, na akcie chodia skoro všetci, je to tá rodinnost' (4). Je dôležité, aby v obci bolo aspoň zopár l'udí, ktorí sú ochotní urobit' niečo pre druhých...Pár aktívnych obyvatelov sa nájde aj v našej obci (2). Ako aktívni, ochotní participovat' na dianí v obci, sú podla slov RK kňazov, obyvatelia z viacerých obcí $(3,10,22,31,14,15)$...Podla mojej skúsenosti sa s l'ud'mi stále dá spolupracovat'. Je potrebné trochu „,hladat' l'udi'“, ale o spoločné veci je stále záujem... (18). Obyvatelia sú aktívni, časté sú stretnutia detí a mládeže na fare ale aj spoločenské akcie, ktoré organizujú miestne spolky spolu so školou v spolupráci aj s obecným úradom a záujmovými organizáciami (38)...Vel'a l'udí je upriamených na chválu, ked' sa aj za maličkost' pochvália, je dobre, ale ako náhle je kritika, hned' každá spolupráca konči. L’udia sú aktívni len ked' sa chvália a vyzdvihujú...Môžem konštatovat', že medzi l'ud’mi (možno hlavne na vidieku) je ešte dostatočný potenciál i ochota venovat' svoju energiu veciam, ktoré súvisia tak s kultúrou, ako aj rozvojom životného prostredia, hlavne ak sa nájde dostatočne presvedčivá osoba, ktorá ich iniciuje (18).

4. Aké problémy máte vobci? Vymenujte ich prosím. Ako tieto problémy vnímate z vášho pohl'adu? Sú to problémy, ktoré sú závažné a prispievate $k$ ich riešeniu, alebo naopak, nie je potrebné vzhl'adom $k$ vašej profesii sa $k$ nim vyjadrovat'? 
Medzi vyšpecifikované problémy, ktoré označili RK kňazi v rámci riadených rozhovorov za najdôležitejšie, boli zahrnuté predovšetkým problémy súvisiace $\mathrm{s}$ morálkou a etikou l'udí. Predovšetkým v oblasti religiozity. Ludia nemajú zábrany, vel'a sa konzumuje alkohol, drogy najmä u mladých l'udí. Je nesúdržnost' rodiny, a celková atmosféra v rodine nie je dobrá. Je vel'ký nárast rozvodov a samovrážd. Je nedostatok morálnych zásad napríklad... smiem ukradnút ked' ma nikto nevidí...(37, 11, 41, 31, 38, 13). Narastajú spoločenské hriechy...Ako závist', nenávist'... Nie sú pozitívne vzory medzi l'ud'mi. Zmenili sa medziludské vztahy, život rodín. Stráca sa rodinné zázemie, mení sa výchova detí. Mladi ludia nemajú záujem o rodinný život, narastá izolovanost’... (12, 38). V našej spoločnosti došlo k pretrhnutiu kontinuity. Staršia generácia, ktorá svojimi postojmi celkom prirodzene vychováva mladšiu, je vel'mi často t’ažko nastavitelná na nový postoj. Mladým l’ud'om, ktorí sa aj snažia, chýbajú modely prevzaté od rodičov a staršich (18). Deti majú vel'a peňazi a vel'a „slobody“ (31). Ludia vidia iba svoje veci, každý preferuje svoje záujmy. Je silný individualizmus. Lud'om chýba elán, nadšenie, ale aj spolupatričnost' a väčši podiel za spoločné dobro...V V̌̌eobecne, už aj na vidieku, prevláda konzumný spôsob života, preferujú sa hmotné statky...Ekonomické záujmy sú prvoradé, je nedostatok financií, každý chce robit' iba biznis, málokto má vztah k umeniu a kultúrne pamiatky, ktoré sú vobciach chátrajú...(20)...Túžba človeka po neobmedzenom rozvoji, t’ažko korigovatel'ná snaha dosiahnut' stále viac, kultúra konzumu a začarovaný kruh zvyšovania nárokov a ich uspokojovania, neochota robit' niečo, čo nie je ekonomicky dostatočne rentabilné (18)...Chýba cukrárěn, kino, denný bar, kde by sa l'udia mohli spoločensky vyžit'...Do spektra vyšpecifikovaných problémov zahrnuli RK kňazi aj problémy súvisiace s technickým vybavením obce ako napríklad chýbajúci vodovod a nevybudovaná kanalizácia $\mathrm{v}$ obciach. Nasledovali problémy ako chýbajúci dom smútku, stará škola, znečist’ovanie obce, vandalizmus, zlá organizácia verejnoprospešných prác, používanie nelegálnych kanalizačných prípojok (41), nelegálne skládky odpadu (38), výtržnosti rekreantov, vel'ký pohyb áut, negatívne vplyvy z cykloturistiky (4), znečist'ovanie vodných tokov zvieracími výkalmi a podobne. Rozvoj obce závisí, podl'a slov RK kňazov, aj od vybudovania inžinierskych sietí...Ak sú vybudované, obec sa môže d'alej rozvíjat'. Dôležitá je najmä kanalizácia... Vážnym problémom je aj prepúštanie l'udí zamestnaných v Chemolaku (6). K závažným problémom patrí aj vysoká nezamestnanost' (1), dochádzka za prácou, vyst’ahovanie mladých rodín, nízke environmentálne vedomie, nedostatok zaujímavých riešení v ponuke agroturistiky, nízka ochota zapojit' sa politicky do diania v obci (3).

\section{Ktoré problémy by ste definovali ako najzávažnejšie, potrebné prioritne riešit?}

Každý vyšpecifikovaný problém má z časového hl’adiska stanovenú inú prioritu riešenia. Ako najdôležitejšiu prioritu označili RK kňazi riešenie 
alkoholizmu predovšetkým u mládeže a u nezamestnanej časti populácie $(37,41)$. Rovnako dôležitá bola pre nich „záchrana“ rodiny, rodinného zázemia, výchova mladej generácie v spoločnosti, výchova v rodine a na školách, vytvorenie priestoru, kde by sa mládež realizovala (záujmové krúžky, programy pre deti a mladistvých, vydávanie časopisu a pod.)...Vediet' zapojit' do procesu nielen deti, ale aj dospelých ludí (38). Medzi priority patrila napríklad obnova morálnych zásad u jednotlivcov (12) a vytvorenie spoločenstiev rodín (31). K d’alším prioritám boli zaradené aktivity súvisiace $\mathrm{s}$ opravou kostola a vybudovaním oddychovej zóny v obci (20). Rovnako bytová otázka je jednou z priorít rozvoja obce z pohl'adu RK kňazov (11). Prioritou je aj zvýšenie zamestnanosti (6). Ako aj brat' vážne svoju vieru (6). K prioritám v rozvoji obce, podl'a slov farára (3), patrí väčšia angažovanost' do riešenia spoločenských problémov, ochota povedat' nahlas svoj názor, ochota politicky zápasit' o dobrú vec, prevencia alkoholizmu napríklad záujmovou činnost'ou mladých...Zamedzit' postupnému vytrácaniu sa komunity z dedin...(18). Dôležité je z pohl'adu farára (15) viac dbat' na hygienické aspekty životného prostredia a zamedzovat' častému znečist'ovaniu životného prostredia.

\section{V čom vidíte hlavné bariéry rozvoja vašej obce?}

Bariéry ktoré bránia rozvoju obce RK kňazi vyšpecifikovali vel'mi konkrétne. Chýba spätná väzba medzi občanmi a vedením obce, koordinácia obecných aktivít a aktivít školy a farnosti (31)...Zjednotit' názory l'udí (38). Bariérou v rozvoji obce môžu byt' aj postoje a zmýšlanie l'udí (12)...Starosta nerobi to, čo by mal. Ludia nie sú s ničím spokojní, ani s farárom ani s lekárnikom. Hned' všetko ofrflú, ale konkrétne sa do ničoho nezapoja... Šikovnejší l'udia z obce odchádzajú do miest (20)... V ostatných obciach nie sú bariéry ani medzi vedením obce a občanmi $(10,22,15)$...Možnou bariérou je politika, ktorá rozdeluje l'udí (37). Bariérou rozvoja je podla slov miestneho kňaza chýbajúca harmónia v duši l'udí, ekológia vonkajšia musím byt' spojená s vnútornou ekológiou (20)...bariérou sú aj medziludské vzt'ahy a financie (6) a neochota a nepochopenie l’udí (2). Bariérou v rozvoji obce môže byt', aj skladba v obecnom zastupitel'stve...Obecné zastupitel'stvo je iba formálne, mali by tam byt' zastúpeni l'udia, ktorí sa neboja kriticky poukázat’ na veci a tiež chýbajú t’ahúni (11)... Bariérou rozvoja obce je jej starosta (41), ale môže to byt' aj vel'kost' obce, nakol'ko v našej obci je nízky počet obyvatelov (3). Bariérou je aj jednostranná orientácia na materiálny zisk a materiálne výhody (18). Podl'a slov miestneho kňaza (44) je bariérou rozvoja obce chýbajúca kanalizácia. Vnašej obci (4) by sme privitali vybudovanie spojovacej cesty smerom na Myjavu, ktorá by umožnila lepši pohyb l'udí a tým zlepšila podmienky zamestnanosti. Niektorí respondenti uviedli vodpovediach potrebu zviditel'nit' obec cez jej rekreačné aktivity... Bariérou je aj sebectvo l'udí a túžba obohacovat' sa...Za totality išli l'udia na brigády zadarmo, dnes nevedia bez zaplatenia nič urobit'. Radšej sa vyhovoria, že nemajú čas... 


\section{Ako sa RK kňazi zapájajú do manažmentu obce? Čo si myslíte, v akej konkrétnej oblasti (v rámci manažmentu a rozvoja obce ) by mali RK kňazi pôsobit'?}

Konkretizovat' zapájanie RK kňazov do rozvoja a manažmentu obce bolo dost' náročné, nakol'ko viacerí duchovní na otázku neodpovedali, prípadne odpovedali vyhýbavo...U nás je to dobré, je tu spolupráca aj porozumenie (37)...Sú tu vel'mi dobré, priatel'ské vzt'ahy. Mala by byt' medzi cirkvou v obci, obecným úradom a družstvom vzájomná spolupráca...(14). Cirkev by nemala zasahovat' do obecných záležitostí a do politiky...lebo participovat'v tejto oblasti nie je úlohou farárov, ale iných l'udí... (12).

L'udia by sa mali viac otvorit' pri riešení svojich problémov (20), cirkev by mala motivovat' mladých l'udí a spolupracovat' aj s rodičmi a dospelými...Dôležitá je vzájomná komunikácia (6), povzbudit' l’udský faktor (2) a viac sa zapájat' do kultúrneho života vobci a pracovat' s det'mi (3). Malo by byt' pri rozvoji a manažmente obce viac zastúpených zástupcov z cirkvi...Aby to boli l’udia, nie podl'a politickej príslušnosti, ale taki, ktorí milujú obec a chcú niečo pre obec urobit'... Podiel cirkvi na rozvoji obce by mal byt' podl'a slov RK kňazov $(10,38)$ primeraný a podla potreby. Mala by byt medzi obecným úradom a farským úradom väčšia spolupráca (22). Táto spolupráca by mala byt' obojstranná, slobodná a profesionálna (41). Cirkev by mala byt' tmeliacim prvkom v dosiahnutí jednoty medzi občanmi (31). Cirkev by sa mala podiel'at' na výchove k spolupatričnosti (komunite)...Výchove kschopnosti naplno žit' aj ked' nie sú všetky materiálne kritériá dokonalé, výchova k hladaniu poctivých riešení, výchova ku vzt'ahu - od prírody po človeka (18). Cirkev by sa mala angažovat', podl'a slov farára (4) predovšetkým vo výchovnej oblasti, aby vplývala na svedomie a charaktery l'udí, čo by následne vplývalo aj na manažment obce. Ale nakol'ko ide o osobnú záležitost', nedá sa to diktovat'. Ďalšou oblastou je oblast' kultúrna, špecificky v etickom zámere a to v rovine všetkých l'udi nielen farníkov.

Konkretizovat' oblast', v ktorej by mohli RK kňazi participovat', bola viac menej jednoznačná. Predovšetkým ide o oblast' duchovnú a oblast' charitatívnu (31), d’alej o prácu s mládežou - výchova (mládež, deti, dospelí), vzdelávanie a oblast' morálky a etiky $(37,12,2,3,10,22,14,18,13,15)$. Miestni kňazi spolupracujú s mládežou, športujú a pripravujú stretnutia detí na prvé sväté prijímanie...Je to vytvorenie jednoty medzi nimi. Organizujú v lete spoločné tábory a pod. (37).

Je vel'mi dôležité, aby cirkev učila, aby bola v kontakte s det'mi a aby ich vychovávala (37)...Úlohou cirkvi je doviest' l'udi k zodpovednosti za materiálne a politické veci, naučit' l'udi férovo sa správat', nepodvádzat', nekradnút' (20). Participovat' v mravnej oblasti a okrem detí venovat' sa aj rodinám, dôchodcom a opusteným l'ud'om (11). Dbat' na medzil'udské vzt’ahy, učit' cudzie reči a spoznávat' umenie (1). Aj výučba anglického jazyka sa dá spojit's náboženstvom. 
Jedna čast' výučby detí je zameraná na potreby školské a v druhej sa venujú náboženstvu...Využivam tieto aktivity $k$ tomu, aby bol kňaz bližšie $k$ lud'om a aby ludia na faru chodili (1). Cirkev by mala participovat' v každej oblasti okrem politiky (41). Cirkev by mala participovat'votázkach nezávislosti, hladania samého seba (31) a v otázkach formovania hodnotovej orientácie (38).

\section{Ako sa Vy konkrétne zapájate do environmentálnych aktivít? Vymenujte tie aktivity, ktoré realizujete a s kým.}

Napriek názoru, že cirkev začala hovorit’ o ochrane životného prostredia už $v$ šest'desiatych rokoch a od tých čias mnoho významných teológov premýšla nad vecami aj z tohto uhla pohladu (18), súčasné zapojenie RK kňazov do aktivít $\mathrm{v}$ environmentálnej oblasti podl'a našich šetrení nie je vysoké. Väčšina duchovných sa $\mathrm{v}$ tejto problematike nepohybuje a nepovažuje ju ani za vhodný okruh, ktorý by mal byt' v ich záujme...Neviem čo by som posúdil, l’udia ani deti sa o životné prostredie nestarajú. Do aktivít v environmentálnej oblasti nie som zapojený $(1,22)$...Neviem čo sa dá robit'...(3). V minulosti si pán farár kupoval pre svoju informovanost' o životnom prostredí časopis Životné prostredie. Konkrétne aktivity však v tejto oblasti nerealizuje. Kázeň je ohlasovanie božieho slova a preto na túto tému v nej nehovorí...A bolo by to aj čudné, ak by som sa angažoval napriklad pri zbere druhotných surovín, ktoré organizuje škola...(12). Naopak niektorí duchovní pravidelne upravujú areál kostola a oslovujú deti v škole, ako aj l’udí v kázňach (homíliách) s problematikou životného prostredia. Vyzývajú miestnych obyvatel'ov, aby sa starali o životné prostredie $(0,37)$. Prihovárajú sa v kázňach $\mathrm{k}$ udržaniu čistoty v obci. Pán farár (37) by chcel presadit' vybudovanie malej teplárne na odrezky...Som kňaz a mám pomáhat', aby duše boli spasené (11)...Kňaz môže v tejto oblasti pomôct' cez kázeň a svätú spoved' (1, 13)...Pôsobit' na ludi cez chrám Boží. Otázky etické, politické aj ekonomické zosúladit' so zákonom viery. Vkladat' do kázní aktuálne témy a zamerat' sa na životnú prax l'udi, aby to citili vo svojom svedomí...(4) Podla pastierskeho listu sa odporúča, aby vkaždej farnosti boli zriadené iniciatívne skupiny, ktoré sa zaoberajú otázkami krest'anského životného štýlu, ekológie a výchovy ksprávnemu vzt’ahu ku stvorenstvu. Môžem potvrdit', že v mnohých farnostiach takéto skupiny existujú (a existovali už aj pred uverejnením výzvy), robia mnoho aktivít ( $i$ ked' možno nepouživajú celé toto pomenovanie) (18).

Podl'a slov RK kňazov treba spoznávat' prírodu a robit' výlety do prírody...upravovat' okolie fary, kosit', viest' deti a občanov k pozitívnemu vzt'ahu $k$ životnému prostrediu...Nemám rád akcie a podujatia, ale snažím sa viest' deti $k$ čistote (20)...napriklad zberom papiera prakticky poukazovat' na problémy životného prostredia a hl'adat' konkrétne riešenia na ich odstránenie. V niektorých obciach sú aktivity duchovných spojené s úpravou záhradky, výsadbou vegetácie (6 a 31) a revitalizáciou lesa (2)...Prispievajú aj príhovory $k$ veriacim v rámci kázní....Cítim sa trochu oklieštený „pedagogickým problémom “ teda že výchova je 
pomalšia ako „niečo urobit”“ (18)... Snažím sa o tom nenápadne hovorit’ a ak sa dá, tak aj niečo urobit'...(14, 38). Pre väčšinu oslovených ide predovšetkým o aktivity v oblasti katechézy (výchovy)... Najpodstatnejši a najdôležitejši zápas je o zmenu človeka a jeho postojov (18). Z odpovedí vyplynulo, že aktivity RK cirkvi $\mathrm{v}$ environmentálnej oblasti by mali byt' primerané a prispôsobené aj $\mathrm{k}$ veku RK kňazov.

\section{Zhrnutie prieskumu}

Cez odpovede na položené otázky sme získali obraz o priamej účasti RK kňazov na živote a pri rozvoji vybraných vidieckych sídiel vokrese Trnava a zaujali stanovisko aj k hypotézam.

Hypotéza 1: Predpokladáme, že rímskokatolícki kňazi vo vidieckych sídlach okresu Trnava zastávajú významné miesto v spoločenskom živote sa čiastočne potvrdila. Rímskokatolícki kňazi plnia v spoločenstve sídiel významnú spoločenskú úlohu. Aktívni sú predovšetkým v kultúrnej oblasti. Za oblast' v ktorej by sa nemali angažovat' viacerí považujú politiku. Podporujú riešenie aj otázok týkajúcich sa ekológie, ochrany životného prostredia a udržatel'ného rozvoja. Pri rozvoji obce deklarujú potrebu spolupráce všetkých zainteresovaných subjektov od starostu obce, miestneho zastupitel'stva, školy, záujmových organizácií aj cirkvi. Za prioritné považujú do spolupráce na rozvoji obce aktivizovat' miestnych obyvatel'ov, kde vidia možnosti pozitívneho vplyvu RK cirkvi cez kázne a ohlasovanie slova božieho.

Hypotéza 2: Predpokladáme, že rímskokatolícki kňazi sa aktívne zapája do environmentálnych aktivít, ktoré prispievajú k zvyšovaniu kvality životného prostredia, ovplyvňujú hodnotovú orientáciu a ekologické povedomia obyvatel'ov a tým ich postoje $\mathrm{k}$ životnému prostrediu, $\mathrm{k}$ prírodným zdrojom a kultúrnym hodnotám a trvalo udržatel'nému rozvoju obce. Hypotéza sa čiastočne potvrdila. RK kňazi ako prioritnú oblast' svojho pôsobenia považujú oblast' duchovnú a charitatívnu. Pozitívne vplývajú na rozvoj morálnych hodnôt a etických hodnôt. Ovplyvňujú hodnotovú orientáciu, medzil'udské vzt’ahy aj ekologické povedomie obyvatel'ov. RK kňazi, ktorí vyučujú náboženskú výchovu na základných školách $\mathrm{v}$ rámci vyučovacieho procesu aktivizujú žiakov $\mathrm{k}$ environmentálnym aktivitám predovšetkým $\mathrm{v}$ oblasti zberu a recyklovania druhotných surovín, ochrany a zvel'ad'ovania okolia školy. V kázňach a honíliách veriacich všetkých vekových kategórií nabádajú k ochrane a tvorbe životného prostredia. V ekologickej oblasti prispievajú $\mathrm{k}$ výchove $\mathrm{k}$ pozitívnemu vzt'ahu $\mathrm{k}$ prírode $\mathrm{s}$ dôrazom na hygienické aspekty životného prostredia a zvyšovanie estetickej stránky obce. Čast' oslovených farárov sa do ekologických aktivít nezapája. Akcie organizuje iba s náboženskou tematikou pre veriacich s dôrazom na staršiu vekovú kategóriu.

Z pohl'adu dížky pôsobenia RK kňazov vo farnosti sme vzhladom na odpovede nezaznamenali výraznejší vzt’ah. Slabší vzt’ah sme zaznamenali 
z pohl’adu vekovej kategórie, kde mladšie a stredné vekové kategórie RK kňazov sú flexibilnejší a viac sa snažia o spoluprácu s obecným úradom, školou, záujmovými organizáciami a miestnymi obyvatel'mi. V rámci spolupráce sa častejšie podielajú na rozvíjaní spoločenského života v obciach. Organizujú rôzne environmentálne, spoločenské a športové podujatia do ktorých sa aj aktívne zapájajú. Aktivitami oslovujú všetky vekové kategórie obyvatel’ov. Pozitívne výsledky dosahujú v oblasti rozvíjania kultúrnych a športových aktivít pre deti a mládež u ktorej pomáhajú rozvíjat' pozitívny vztah k prírode a životnému prostrediu. RK kňazi vyššieho veku (nad 60 rokov), sú k otázkam rozvoja obce opatrnejší. Viac sa izolujú od života v obci a sústred'ujú sa na otázky viery. Obávajú sa o budúcnosti RK cirkvi. Cítia, že RK cirkev je v zániku a snažia sa $\mathrm{v}$ poslednej chvíli ešte pozitívne vplývat' na l'udí a aktivizovat' ich $\mathrm{k}$ viere a $\mathrm{k}$ náboženstvu. Rovnako čast' RK kňazov je síce aktívna a komunikatívna, ale aktivity zameriava iba na cirkevnú problematiku.

Výber techniky a zberu dát formou riadeného rozhovoru nám vhodne doplnil informácie získané z doterajších krajinnoekologických výskumov a sociologických prieskumov realizovaných formou dotazníkov.

\section{Záver}

V príspevku sme sa zamerali na prezentáciu iba časti výskumu realizovaného s RK kňazmi vo vybraných sídlach okresu Trnava. Výskum potvrdil skutočnost', že RK kňazi sú nielen vysoko vzdelaní l'udia, ale aj vel'mi komunikatívni. Vedia sa orientovat' vo viacerých nielen spoločenských otázkach, ale aj odborných vrátane hodnotenia kvality života, životného prostredia, l'udského potenciálu a pod. Dokážu zaujat' aj kritické postoje na mnohé problémy. Majú schopnost' presne špecifikovat' svoje názory. Vedia hl'adat' a ponúknut' alternatívy riešenia na zlepšenie situácie.

Na základe získaných názorov od RK kňazov treba zdôraznit', že pre rozvoj obcí a optimálne fungovanie samosprávy je dôležitá:

$\checkmark$ Väčšia angažovanost' a participácia jednotlivých subjektov vrátane RK cirkvi do riešenia spoločných problémov - sociálnych, ekonomických aj environmentálnych ako aj do otázok týkajúcich sa rozvoja a manažmentu obcí podporujúcich zvyšovanie kvality života a životného prostredia.

$\checkmark$ Väčšia spolupráca medzi jednotlivými subjektmi pôsobiacimi v obci a väčšia koordinácia ich aktivít. Vytvorenie spätnej väzby medzi vedením obce, RK cirkvou a ostatnými subjektmi.

$\checkmark$ Väčšia participácia zástupcov RK cirkvi aj pri riešení environmentálnych problémov (zapájat' sa do aktivít organizovaných obecným úradom, školou, záujmovými organizáciami a pod.). Smerovat' viac záujem RK kn̆azov aj do otázok týkajúcich sa zachovania vlastnej 
identity obce, histórie obce, záchrany kultúrnych pamiatok, oživenia miestnych zvykov a tradícií, zvýšenia estetickej stránky obce a pod.

$\checkmark$ Do budúcnosti väčšia angažovanost' RK kňazov v charitatívnej oblasti, pri formovaní hodnotovej orientácie obyvatel'ov, zvyšovaní environmentálneho povedomia obyvatel'ov, a ovplyvňovaní ich postojov k životnému prostrediu, pri podnecovaní mladých l'udí žit' na vidieku, aby sa prinavrátila mladá generácia na vidiek.

Získané výsledky je možné využit' na lokálnej aj regionálnej úrovni. V miestnej politike napríklad voblasti riadenia životného prostredia, v regionálnom rozvoji pri začlenení environmentálnych aspektov a aspektov udržatel'nosti do priestorového plánovania.

\section{Pod'akovanie}

Príspevok vznikol ako výstup vedeckého projektu APVV - 17 - 0377 s názvom Hodnotenie novodobých zmien a vývojových trendov polnohospodárskej krajiny Slovenska.

\section{Literatúra}

DENZIN, N. K. - LINCOLN, Y. S. 1994. Introduction: Entering the field of qualitative research. In Denzin, N. K. - Lincoln, Y. S. (eds.) Handbook of qualitative research. Sage Publications. California: Thousand Oaks, pp. 1-17.

CHRENŠČOVÁ, V. 2011. Kvalita životného prostredia z pohl'adu miestneho obyvatel'stva na území chránenej krajinnej oblasti Horná Orava. In Geografický časopis. roč. 63 , č. 1 , s. 69-85.

IZAKOVIČOVÁ, Z. - MOYZEOVÁ, M. - BEZÁK, P. - DOBROVODSKÁ, M. GROTKOVSKÁ, L. - HRNČIAROVÁ, T. - KENDERESSY, P. KRNÁČOVÁ, Z. - MAJERČÁK, J. - MIKLOŠOVIČOVÁ, Z. - MOYSES, M. - PAVLÍČOVÁ, K. - PETROVIČ, F. - ŠPULEROVÁ, J. ŠTEFUNKOVÁ, D. - VÁLKOVCOVÁ, Z. 2008. Hodnotenie pol'nohospodárskej krajiny v tranzitívnej ekonomike. Bratislava: Ústav krajinnej ekológie Slovenskej akadémie vied, 2008. $298 \mathrm{~s}$.

IZAKOVIČOVÁ, Z. - GROTKOVSKÁ, L. - MOYZEOVÁ, M. - VODIČKOVÁ, M. - CIBIRA, P. - HREŠKO, J. - ŠTEFUNKOVÁ, D. - HALADA, L. DAVID, S. - KENDERESSY, P. - PETROVIČ, F. - BOLTIŽIAR, M. GRAMBLIČKOVÁ, V. - IMRICHOVÁ, Z. - MIKLOŠOVIČOVÁ, Z. 2006. Integrovaný manažment krajiny II. Bratislava: ÚKE SAV, 2006. 232 s. ISBN 80-969272-9-9.

MAJO, R. 2017. Premeny náboženských pomerov na Slovensku v dynamickom 20. storočí. Katedra humánnej geografie a demografie, Prírodovedecká fakulta UK v Bratislave. Text $\mathrm{k}$ prednáške. $16 \mathrm{~s}$. 
MAŘÍKOVÁ, H. - PETRUSEK, M. - VODÁKOVÁ, A. 1996. Vel'ký sociologický slovnik I. Praha: Karolinum, 1996. 747 s. ISBN 80-7184-164-1.

MOYZEOVÁ, M. 2004. Hodnotenie vplyvov na ekologickú štruktúru krajiny v podmienkach hospodársky intenzívne využivaného regiónu (na príklade modelového územia okresu Trnava). Dizertačná práca. Bratislava: Ústav krajinnej ekológie Slovenskej akadémie vied, 2004. $152 \mathrm{~s}$.

MOYZEOVÁ, M. - MIKLÓS, L. - ŠATALOVÁ, B. - IZAKOVIČOVÁ, Z. OSZLÁNYI, J. - KENDERESSY, P. - ŠTEFUNKOVÁ, D. - KRNÁČOVÁ, Z. 2015. Hodnotenie kvality životného prostredia vidieckych sídiel (na príklade vidieckych sídiel okresu Trnava). Bratislava: Ústav krajinnej ekológie Slovenskej akadémie vied, 2015. $280 \mathrm{~s}$.

MOYZEOVÁ, M. - IZAKOVIČOVÁ, Z. 2016. Attitudes of the involved subjects to the issue of biodiversity conservation in the protected area of the Malé Karpaty Mts. (results of personal interviews). In Ekológia (Bratislava). vol. 35, no. 4, pp. 392-400.

ŠTATISTICKÁ ROČENKA SLOVENSKEJ REPUBLIKY. 2017. Štatistický úrad SR. Bratislava: VEDA, 2017. 664 s.

\section{PERSPECTIVES OF DEVELOPMENT OF RURAL SETTLEMENTS IN TRNAVA DISTRICT FROM THE POINT OF VIEW OF ROMAN CATHOLIC PRIESTS (RESULTS OF SOCIOLOGICAL RESEARCH)}

\section{Summary}

The paper is an example of the assessment of sociological research carried out by means of interviews. Roman Catholic priests presented their views on eight groups of questions concerning the social life in communes, human potential, and environmental issues.

1. What is your opinion of social life in your commune? What events (social, cultural, etc.) do you organize? Who is the principal organizer?

2. Do you take part in your commune's social life? If so, in what way?

3. What is your opinion of local people's activity?

4. Are there any issues in the commune? Specify please. How do you perceive those issues? Are they serious and you contribute to their solution or it is not necessary, regarding your profession, to comment them?

5. Which issues are the most serious and need priority solutions?

6. What are the principal barriers to the development of your commune?

7. How does Roman Catholic priests participate in the communal management? In your opinion, is there any concrete part of the 
communal management and development where Roman Catholic priests should participate?

8. Do you personally take part in environmental activities? Quote the ones in which you participate and with whom.

The research partially confirmed the hypothesis 1 that Roman Catholic priests in rural settlements have important position communal life. The research partially confirmed also hypothesis 2 , that Roman Catholic priests are actively participating in environmental activities contributing to increase of environment quality and they have impact on priorities and environmental awareness of inhabitants.

Inclusion of research results into development documents may contribute to harmony of development in settlements with their natural and cultural potential.

\section{RNDr. Milena Moyzeová, PhD.}

Ústav krajinnej ekológie SAV

Štefánikova 3, P.O.BOX 254, 81499 Bratislava

E-mail: milena.moyzeova@ savba.sk

Doc. RNDr. Zita Izakovičová, PhD.

Ústav krajinnej ekológie SAV

Štefánikova 3, P.O.BOX 254, 81499 Bratislava

E-mail: zita.izakovicova@ savba.sk 